\title{
AC 2008-131: VARIATION IN COMPUTING THE LENGTH FACTOR IN THE UNIVERSAL SOIL LOSS EQUATION
}

\section{Ernest Tollner, University of Georgia-Athens}

Dr. Ernest W. Tollner is a native of Maysville, KY and received his BS and MS degrees in agricultural engineering at the University of Kentucky. He did his doctorate at Auburn. His graduate work was concerned with computer modeling erosion control, water resource development and animal waste management. This work provided the foundation for extension into composting, bioconversion and imaging research. Dr. Tollner was among the first to use topographic scanning for charactering soils, food products and logs. Research over the past 25 years at the University of Georgia has resulted in over 100 publications and 3 patents. 


\title{
Variation in computing the Length Factor in the Universal Soil Loss Equation
}

\author{
Ernest W. Tollner
}

\begin{abstract}
The universal soil loss equation, $A=R * K * L * S * C * P$, estimates average annual soil loss A based on rainfall $(\mathrm{R})$, soil factor $(\mathrm{K})$, length factor $(\mathrm{L})$, slope $(\mathrm{S})$, effective cover factor $\mathrm{C}$, and a practice factor $\mathrm{P}$. In teaching the use of the relationship, students can find values of $\mathrm{R}$ on maps, soil factor in tables based on a soil classification readily available in soil surveys, slope $\mathrm{S}$ may be estimated from the topographic map of the site., the cover factor $\mathrm{C}$ may be ascertained based on a specified crop rotation and the erosion handbook and the practice factor $\mathrm{P}$ may be determined from the erosion handbook for specified conservation practices such as terracing, contouring, etc. One source of variation in estimates is to arrive at meaningful slope length $\mathrm{L}$. The erosion handbook suggests that one look for the length of the steepest segments of slope in the typical field of variable slope but leaves to judgment the actual quantification. The paper will report on the variation in techniques that students and professionals learn and use when asked to implement this procedure. A new approach for making a quantitative estimate of the length factor will be presented and compared with research data.
\end{abstract}

\section{Introduction}

The universal soil loss equation, $A=R * K * L * S * C * P$, estimates average annual soil loss $A$ based on rainfall $(\mathrm{R})$, soil factor $(\mathrm{K})$, length factor $(\mathrm{L})$, slope $(\mathrm{S})$, effective cover factor $\mathrm{C}$, and a practice factor $\mathrm{P}$. In teaching the use of the relationship, students can find values of $\mathrm{R}$ on maps, soil factor $(\mathrm{K})$ in tables based on a soil classification readily available in soil surveys, slope $\mathrm{S}$ may be estimated from the topographic map of the site., the cover factor $\mathrm{C}$ may be ascertained based on a specified crop rotation and the erosion handbook tables, and the practice factor $\mathrm{P}$ may be determined from the erosion handbook tables for specified conservation practices such as terracing, contouring, etc. The rainfall parameter quantifies the interrelated erosive forces of rainfall and runoff that are the direct results of the rainstorms. The soil erodibility parameter $\mathrm{K}$ estimates the long term soil response to rainfall and runoff erosive forces. In absence of organic matter data, tabulated $K$ values may selected based on the soil textural class. The crop management $(C)$ parameter may be calculated using a subfactor approach developed in Renard et al (1997) or based on tables shown in the same reference. Tabulated $P$ values recommended by Renard et al (1997) were used. The slope length parameter relates the effect of the slope length on soil loss since there is greater accumulation of runoff on longer lengths and more runoff volume leads to high runoff velocities, thus more soil loss. The slope length parameter may be calculated using method described by Renard et al (1997). In essence, five of the six factors of the USLE are, generally speaking, consistently estimated by various practitioners. The slope length factor $\mathrm{L}$ is an exception to this rule, prompting this enquiry into why such variation exists. 


\section{Defining the Problem}

Interest in the length factor of the USLE was piqued a few years ago when a group of senior design students who had taken my course began working with an extension colleague on a project involving the estimation of average annual erosion from an agricultural field. Three students computed three very different estimates and the variation was due to differences in the way one selects the length factor. As the instructor of the Introduction to Natural Resources Engineering course where the students would be expected to learn how to use the USLE, this caused some consternation and reflection. I asked this colleague how he would have made the calculation, and saw quickly how students could get different answers for a typical field as shown in Figure 1.

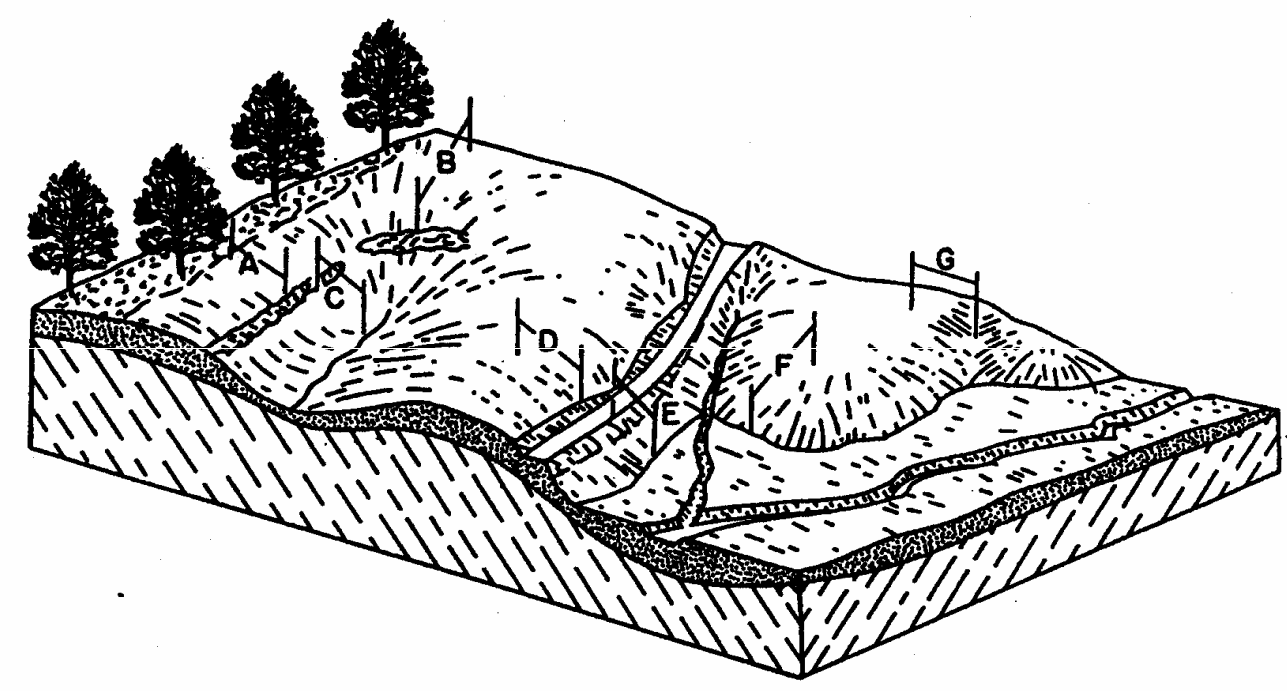

Figure 1. Typical slope lengths. Slope A- If undisturbed forest soil above does not yield surface runoff, the top of slope starts with edge of undisturbed forest soil and extends down slope to windrow if runoff is concentrated by windrow. Slope B-Point of origin of runoff to windrow if runoff is concentrated by windrow. Slope C-From windrow to flow concentration point. Slope D-point of origin of runoff to road that concentrates runoff. Slope E-From road to flood plain where deposition would occur. Slope F-an nose of hill, from point to origin of runoff to flood plain where deposition would occur .Slope G-Point of origin of runoff to slight depression where runoff would concentrate. In practice, one would 1) determine the slope length factor and 2) the slope factor for each of the identified lengths, then 3) take an average of the LS products to represent the field (from Renard et al., 1997; used courtesy of USDA-ARS).

For about 10 students, the answers ranged from the upper most point on the field to the drainage outlet $-60 \%$; from the upper most point on the field to the nearest stream $-10 \%$; the length of the stream $-10 \%$; the length of a steep reach such as one of the lettered points in Figure 1 $10 \%$; and, other $-10 \%$. In other words, most students missed this. The question is why?

The answer likely lies in the instructional resources and methods used in teaching how to determine the relevant length. Most students have just covered how to calculate the time of concentration for a watershed using a common technique that requires the measurement the average slope of a watershed to an outlet, explaining why $60 \%$ may have made this choice on the slope length. The topic is usually covered in a survey introduction that necessitates a hurried 
passage over these empirical factors. One must also ask how we as instructors were taught and from what did we typically learn?

This experience prompted a search of materials likely to be commonly used in instruction. A summary is shown in Table 1. The texts with ratings of 4 or 5 in Table 1 generally discuss how the length factor was determined in the experimental work leading to the USLE or its variations. The 22 meter long plot is mentioned and relationships are given to adjust the length for shorter or longer plots. Uniform slopes are the order of the day. Also, it seems that the discussion of erosion in texts is still mired in the old conventional tillage paradigm that has been largely replaced by conservation tillage in practice. Consider the exam question scenario in Figure 2. The field area is uniformly sloped and the entire area is to be disturbed. The slope length here is correctly stated as the length from the top of the runoff to the stream, normal to the contours. Occasional students want to go with the maximum diagonal to the outlet. The point is that most student problems are simple extensions of the experimental plot. Most students never encounter the scenario shown in Figure 1 until they have left the class room and thus may not be prepared to deal with a typical problem that a conservation tillage scenario may impose. In other words, students going from the course to the field would typically not have a clear idea of where to place the beginning point or the ending point of a relevant length measurement for erosion control work.

The more advanced literature in the field does point to a consistent instruction for length determination. Starting at the beginning of where flow lines may converge and going to a point where the lines diverge (slope changes and deposition is likely) or where the flow encounters a defined stream or flow collection is the criteria. Students have to learn how to identify the points of convergence/discharge and they typically do not.

\section{Solution}

Ssegane (2007) was doing watershed assessment work in Africa and project requirements were to develop an erosion sensitivity map. Although the thrust of the project was to use advanced GIS techniques, we also wanted to develop a quick, back-of-the-envelope approach using approaches such as GoogleEarth. He developed a methodology for making area and length measurements with good success. Elevation measurements were also made. The Google ${ }^{\mathrm{TM}}$ Earth Pro coordinates were translated using three dimensional (3D) modeling software to generate vector diagram depicting runoff direction, site contour map, and a three dimensional representation of the watershed. The vector map was overlaid over the original Google ${ }^{\mathrm{TM}}$ Earth Pro image to define the probable runoff direction. The flow length was defined as the longest flow path depicted by the vector direction to the flume location. From the overlaid vector map, the Google ${ }^{\mathrm{TM}}$ Earth Pro measure tool was used to estimate the slope length and subsequently the slope gradient. Figures 3 and 4 illustrate determination of the slope length and slope gradient for the disturbed land plus slope gradient. Vectors with longer arrows (Figure 4) indicate a steeper slope thus runoff from such areas can influence the direction of runoff from less steeper slopes. This technique lead to excellent agreement in predicted average annual erosion vs. measured average annual erosion on watersheds in the US and in Uganda. Additional details are provided in Ssegane et al 2007. 
Table 1. Summary of selected treatments of the topographic factors in the Universal Soil Loss Equation.

\begin{tabular}{|c|c|c|c|}
\hline LS Computation method & Length evaluation & $\begin{array}{l}\text { Instruction } \\
\text { Use rating }^{1}\end{array}$ & Source \\
\hline $\begin{array}{l}\text { Calculated behind the scenes presumably using } \\
\text { standard USLE formulas for length and slope. }\end{array}$ & $\begin{array}{l}\text { Point where overland flow begins until 1) } \\
\text { enters a well defined channel, or 2) slope } \\
\text { flattens so deposition occurs }\end{array}$ & 1 & $\begin{array}{l}\text { Anon } \\
1998\end{array}$ \\
\hline $\begin{array}{l}\text { Simple calculations for the length and slope factors. A } \\
\text { technician level treatment. Typical of extension } \\
\text { bulletin treatment. }\end{array}$ & $\begin{array}{l}\text { Point where overland flow begins until 1) } \\
\text { enters a well defined channel, or 2) slope } \\
\text { flattens so deposition occurs }\end{array}$ & 3 & $\begin{array}{l}\text { Beasley } \\
\text { et al } 1984\end{array}$ \\
\hline Geological perspective on USLE applications. & $\begin{array}{l}\text { Length is sometimes taken as the slope } \\
\text { length of an entire site but should be } \\
\text { regarded as the length of uninterrupted water } \\
\text { flow }\end{array}$ & 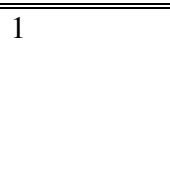 & $\begin{array}{l}\text { Curran et } \\
\text { al } 1994\end{array}$ \\
\hline $\begin{array}{l}\text { Simple calculations for the length and slope factors. } \\
\text { This } 5^{\text {th }} \text { edition text began as a text that predated the } \\
\text { USLE. Text presented a simplified version suitable } \\
\text { for first-timers that grew with the science. }\end{array}$ & Discussed the $22 \mathrm{~m}$ standard plot. Uniform slopes were assumed and the entire length was used. & 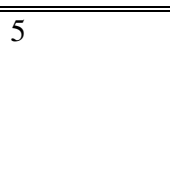 & $\begin{array}{l}\text { Fangmier } \\
\text { el al } 2006\end{array}$ \\
\hline $\begin{array}{l}\text { Advanced modeling discussion and simple } \\
\text { calculations for each factor. A very detailed treatment } \\
\text { of the science behind the factors. The most modern } \\
\text { rigorous treatment. }\end{array}$ & $\begin{array}{l}\text { Length of segments on the topography } \\
\text { having parallel flow lines. Advanced } \\
\text { modeling context. Length not as major due } \\
\text { to multiple segments. }\end{array}$ & 2 & $\begin{array}{l}\text { Foster, } \\
2005\end{array}$ \\
\hline $\begin{array}{l}\text { Advanced modeling discussion and simple } \\
\text { calculations for each factor. Describes the } \\
\text { multisegment approach. }\end{array}$ & $\begin{array}{l}\text { Advanced modeling context. Length not as } \\
\text { major due to multiple segments. }\end{array}$ & 2 & $\begin{array}{l}\text { Haan et al } \\
1994\end{array}$ \\
\hline $\begin{array}{l}\text { Looked at the combined LS factors and nomographs. } \\
\text { USLE came into this hydrology text due to water } \\
\text { quality issue interests. }\end{array}$ & Discussed the $22 \mathrm{~m}$ standard plot. & 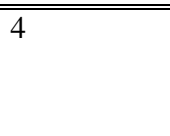 & $\begin{array}{l}\text { McCuen } \\
2004\end{array}$ \\
\hline $\begin{array}{l}\text { Advanced modeling discussion and simple } \\
\text { calculations for each factor. A very detailed treatment } \\
\text { of the science behind the factors }\end{array}$ & $\begin{array}{l}\text { Showed a sketch of a typical topography and } \\
\text { that one measured the lengths of several } \\
\text { steep slope segments }\end{array}$ & 2 & $\begin{array}{l}\text { Renard et } \\
\text { al } 1997\end{array}$ \\
\hline $\begin{array}{l}\text { This Handbook of Hydrology treatment looked as the } \\
\text { LS factors combined and used a nomograph. }\end{array}$ & Discussed the $22 \mathrm{~m}$ standard plot. & 2 & $\begin{array}{l}\text { Shen and } \\
\text { Julien } \\
1993\end{array}$ \\
\hline Simple calculations for the length and slope factors. & $\begin{array}{l}\text { Discussed the } 22 \mathrm{~m} \text { standard plot. Disturbed } \\
\text { areas were treated as long uniform slopes } \\
\text { where the entire length was used. }\end{array}$ & "4 & $\begin{array}{l}\text { Tollner } \\
2002\end{array}$ \\
\hline
\end{tabular}


1. ( 30 points) Compute the 100 year peak runoff and soil loss|from the field shown below that is located near Atlanta.

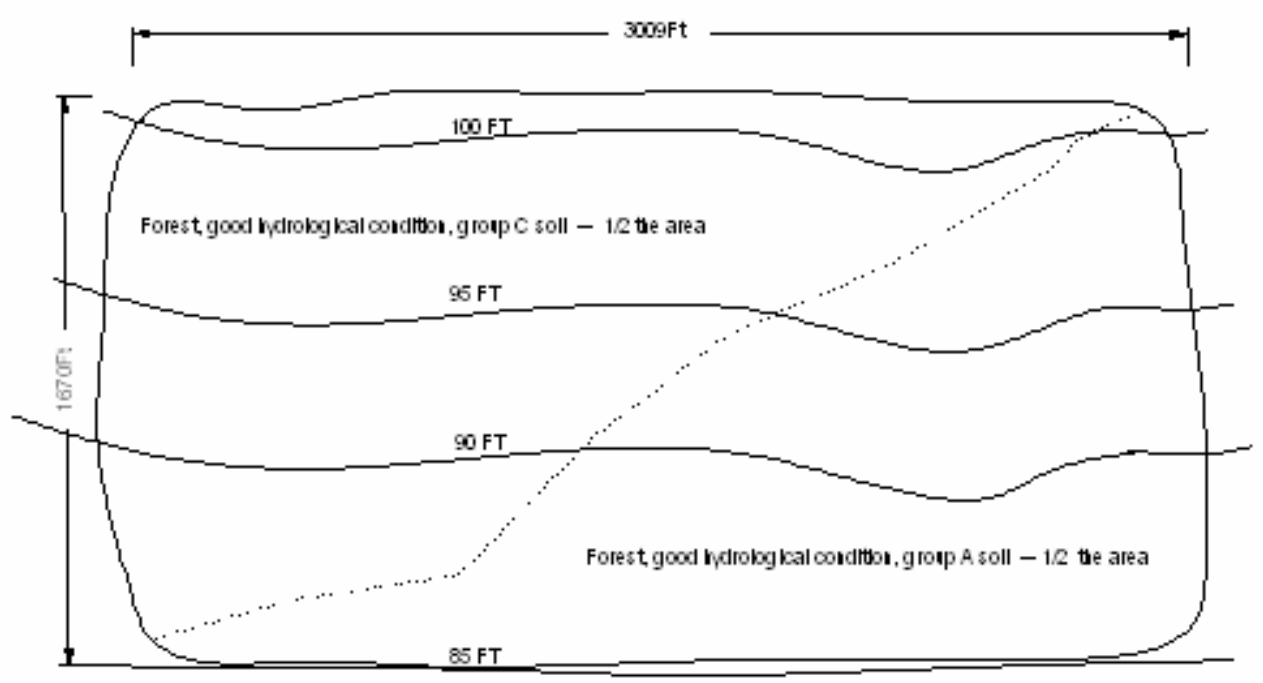

Strean wit vp 6 ttsec

ôttet

Figure 2. Typical exam problem scenario for evaluating USLE along with runoff in a potential development scenario where land would be cleared.

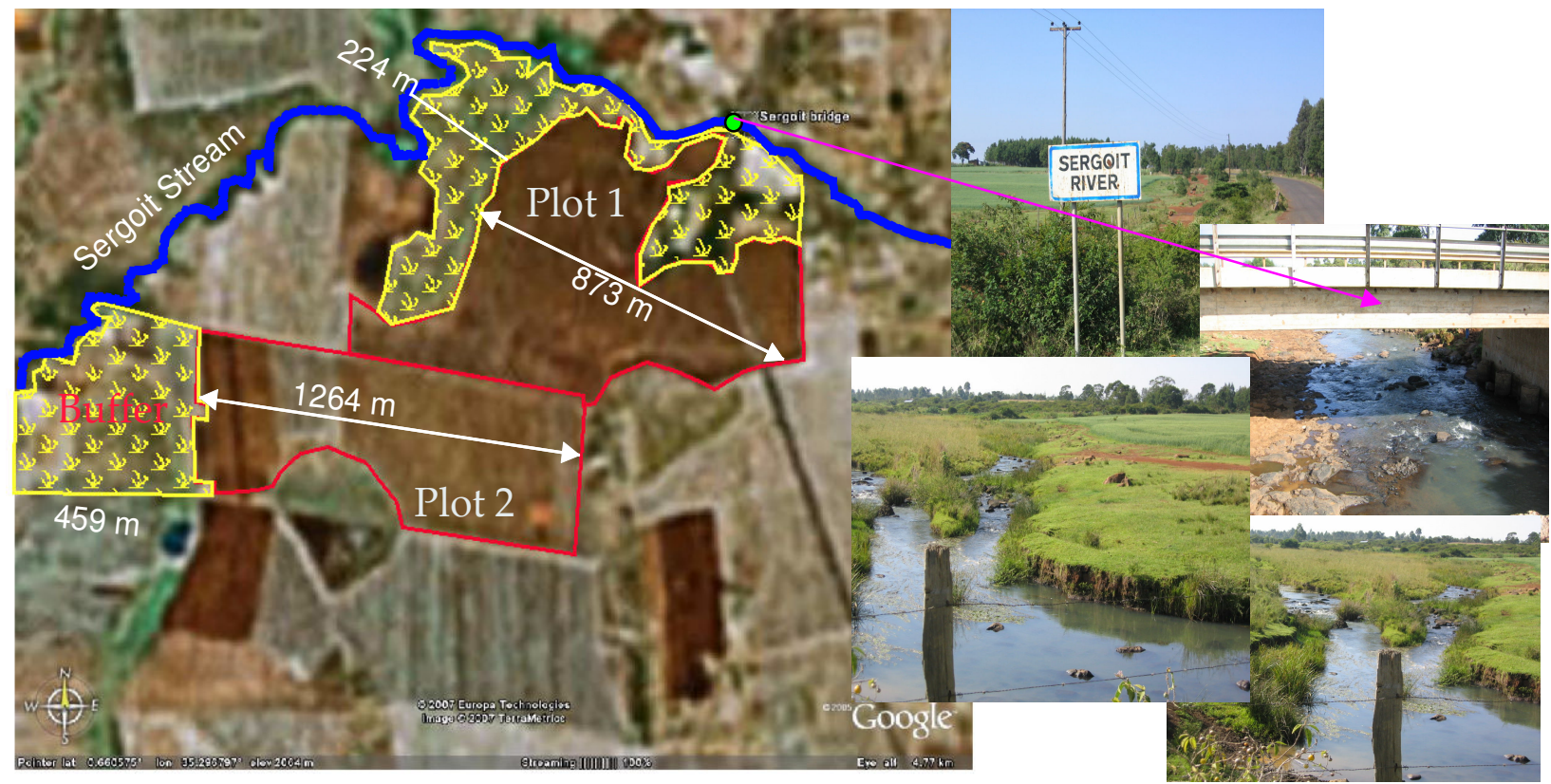

Figure 3. Field site on the Sergoit stream, a tributary of the Nzoia River with measurements superimposed on images and photographs of the site (from Ssegane et al 2007). 


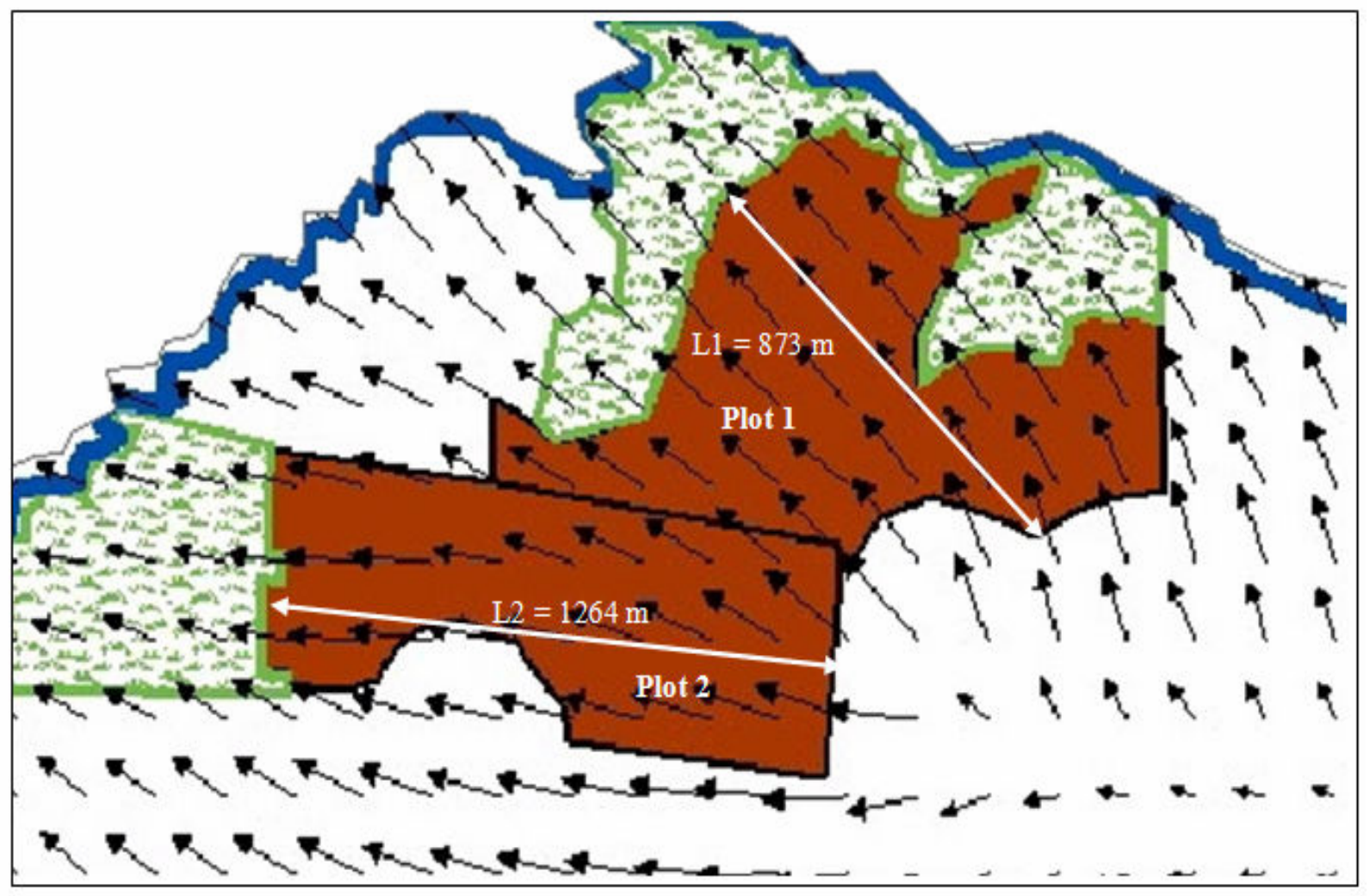

Figure 4. The stream flow patterns of the site in Figure 2 based on Image derived elevations and analysis with a topological analysis software package (from Ssegane et al 2007).

\section{Implemtation}

The detailed solution to the erosion length factor is ideally shown in Figure 4, where the slope length would be taken as the length where the flow lines are parallel. The length in plot 1 would be the actual length of $873 \mathrm{~m}$ while the length of plot two would be about $400 \mathrm{~m}$ instead of the length of $1264 \mathrm{~m}$.

The length factor determination could be taught in a straightforward way by having a DEM of the site in question, and having students learn to rapidly sketch these flow lines. If they are working with civil design software, the capability is rapidly appearing and so could be done directly.

Problem solving and assessment needs to move beyond the simple uniform slope problem such as shown in Figure 2 to a more complex topography. 


\section{References}

Anon. 1998. Point module V - USLE Erosion. In the special NRI study, USDA-NRCS, available at ftp://ftp-fc.sc.egov.usda.gov/NCGC/products/nri/1997-1999nri/ptmod598.pdf.

Curran, J.H., M.D. Watkins and D.W. Tubbs. 1994. Application of the universal soil loss equation in estimating relative sediment yields associated with urbanization. See www.tubs.com/abstract/usle_abs.htm. Abstract with program, Annual meeting of the Geological Society of America, Seattle WA.

Fangmier, D.D., W.J. Elliot, S.R. Workman, R.L. Huffman and G.O. Schwab. 2006. Soil and water conservation engineering. Thompson Delmar Learning, New York, NY.

Foster, G.R. 2005. Revised Universal Soil Loss Equation version 2 (RUSLE2): Science documentation. See http://www.ars.usda.gov/Research/docs.htm?docid=6010. Agricultural Research Service, US Dept. Agr., Washington, DC.

Haan, C.T., B.J. Barfield and J.C. Hayes. 1994. Design hydrology and sedimentology for small catchments. Academic Press, New York, NY.

McCuen, R.H. 2005. Hydrologic analysis and design. Prentice Hall, Upper Saddle River, NJ.

Moore, I.D. and G.J. Burch. 1986. Physical basis of the length-slope factor in the universal soil loss equation. SSSA Jour. 50:1294-1298.

Renard, K.G., G.R. Foster, G.A. Weesies, D.K. McCool and D.C. Yoder. 1997. Predicting soil erosion by water: A guide to conservation planning with the revised universal soil loss equation (RUSLE). USDA-ARS Pub ARS-S40. Agricultural Research Service, US Dept. Agr., Washington, DC.

Shen, H.W. and P.Y. Julien. 1993. Erosion and sediment transport. IN Handbook of Hydrology, D.R. Maidment (Ed.). McGraw-Hill, New York, NY.

Ssegane H., E. W. Tollner, and S. C. McCutcheon.2007. Erosion prediction on microwatersheds using topographic parameters derived from global observatory tools. Submitted to Transactions of the ASABE. Am. Soc. Agr. \& Bio. Engrs., St. Joseph, MI.

Tollner, E.W. 2002. Introduction to natural resources engineering. Iowa State Univ. Press, Ames, IO. 